\title{
Inequalities in healthcare disruptions during the Covid-19 pandemic: Evidence from 12 UK population-based longitudinal studies
}

Authors:

Jane Maddock $^{1} \wedge$, Sam Parsons ${ }^{2} \wedge$ Giorgio Di Gessa ${ }^{3} \wedge$, Michael J. Green ${ }^{4} \wedge$, Ellen J. Thompson ${ }^{5}$, Anna J. Stevenson ${ }^{6}$, Alex S.F. Kwong ${ }^{6,7}$, Eoin McElroy ${ }^{8}$, Gillian Santorelli ${ }^{9}$, Richard J. Silverwood ${ }^{2}$, Gabriella Captur ${ }^{2}$, Nish Chaturvedi ${ }^{1}$, Claire J. Steves ${ }^{5}$, Andrew Steptoe ${ }^{3}$, Praveetha Patalay ${ }^{1,2}$, George B. Ploubidis ${ }^{2}$, Srinivasa Vittal Katikireddi ${ }^{4 *}$

^Joint first authors

1 MRC Unit for Lifelong Health and Ageing, University College London

2 Centre for Longitudinal Studies, UCL Social Research Institute, University College London

3 Institute of Epidemiology and Health Care, University College London

4 MRC/CSO Social \& Public Health Sciences Unit, University of Glasgow

5 Department of Twin Research and Genetic Epidemiology, School of Life Course Sciences, King's

College London

6 Division of Psychiatry, University of Edinburgh

7 MRC Integrative Epidemiology Unit, University of Bristol

8 Department of Neuroscience, Psychology and Behaviour, University of Leicester

9 Born in Bradford, Bradford Institute for Health Research, Temple Bank House, Bradford Royal Infirmary

*Correspondence to: Prof. Srinivasa Vittal Katikireddi, MRC/CSO Social \& Public Health Sciences Unit, University of Glasgow. vittal.katikireddi@glasgow.ac.uk

\section{People acknowledgments:}

GS: Drew Altschul, Chloe Fawns-Ritchie, Archie Campbell, Robin Flaig.

ALSPAC: Daniel J Smith, Nicholas J Timpson, Kate Northstone.

Understanding Society: Michaela Benzeval

TwinsUK: Deborah Hart, María Paz García, Rachel Horsfall, Ruth C.E. Bowyer.

CLS: Matt Brown, Lisa Calderwood, Emla Fitzsimons, Alissa Goodman, Aida Sanchez

NSHD: Andrew Wong, Maria Popham, Karen MacKinnon, Imran Shah, Philip Curran 
medRxiv preprint doi: https://doi.org/10.1101/2021.06.08.21258546; this version posted June 12, 2021. The copyright holder for this preprint (which was not certified by peer review) is the author/funder, who has granted medRxiv a license to display the preprint in perpetuity.

It is made available under a CC-BY 4.0 International license .

\begin{abstract}
Background: Health systems worldwide have faced major disruptions due to COVID-19 which could exacerbate health inequalities. The UK National Health Service (NHS) provides free healthcare and prioritises equity of delivery, but the pandemic may be hindering the achievement of these goals. We investigated associations between multiple social characteristics (sex, age, occupational social class, education and ethnicity) and self-reported healthcare disruptions in over 65,000 participants across twelve UK longitudinal studies.
\end{abstract}

Methods: Participants reported disruptions from March 2020 up to late January 2021. Associations between social characteristics and three types of self-reported healthcare disruption (medication access, procedures, appointments) and a composite of any of these were assessed in logistic regression models, adjusting for age, sex and ethnicity where relevant. Random-effects meta-analysis was conducted to obtain pooled estimates.

Results: Prevalence of disruption varied across studies; between 6.4\% (TwinsUK) and $31.8 \%$ (Understanding Society) of study participants reported any disruption. Females (Odd Ratio (OR): 1.27 [95\%CI: $1.15,1.40] ; \mathrm{I}^{2}=53 \%$ ), older persons (e.g. OR: 1.39 [1.13,1.72]; $\mathrm{I}^{2}=77 \%$ for $65-75 \mathrm{y}$ vs 45 $54 \mathrm{y}$ ), and Ethnic minorities (excluding White minorities) (OR: $1.19[1.05,1.35] ; \mathrm{I}^{2}=0 \%$ vs White) were more likely to report healthcare disruptions. Those in a more disadvantaged social class (e.g. OR: $1.17[1.08,1.27] ; \mathrm{I}^{2}=0 \%$ for manual/routine vs managerial/professional) were also more likely to report healthcare disruptions, but no clear differences were observed by education levels.

Conclusion: The COVID-19 pandemic has led to unequal healthcare disruptions, which, if unaddressed, could contribute to the maintenance or widening of existing health inequalities. 


\section{Introduction}

The coronavirus disease 2019 (COVID-19) pandemic is profoundly affecting all aspects of society. Health systems world-wide have faced major disruption as they respond to large increases in demand arising from the COVID-19 disease. $^{1-4}$ Furthermore, healthcare access has been reduced by governmental control measures and the public's fear of contracting infection. ${ }^{5}$ Disruptions may have both short and long-term health consequences as preventive treatments are foregone, disease surveillance is interrupted and disease diagnoses are delayed. While the disruption of health systems can impact the entire population, it has become apparent that not all groups have been affected equally. Understanding the impacts of the pandemic on health systems and on equity of healthcare access is therefore a major policy priority.

In the UK, the National Health Service (NHS) provides free healthcare and prioritises equity of delivery. However, the UK's relatively high COVID-19 burden and associated repeated lockdown measures have raised concerns that the health system may not be providing accessible care to those who need it most. Recent reports from NHS Digital indicate a large increase in those waiting 12 months or more for elective treatments in February 2021 compared to March 2020. ${ }^{6}$ Furthermore, despite decreases in attendance at accident and emergency services, ${ }^{4}$ the number of patients waiting over 12 hours for admission was 34\% higher in January 2021 than January 2020. Disruption to pharmacological treatments has also been reported with delays in accessing medication. ${ }^{7,8}$ However, a comprehensive assessment of inequalities in healthcare disruption in the community is lacking.

It is well known that health systems do not meet the needs of all social groups equitably, with marked health inequalities by sex, ethnicity, and socioeconomic position. ${ }^{9,10}$ For example, the inverse care law demonstrates that health service provision is often not allocated according to need, with more socioeconomically deprived areas relatively under-served. ${ }^{11}$ Given the barriers that some social groups face in accessing high quality healthcare, there is considerable concern that disadvantaged groups (e.g., ethnic minorities) will be disproportionately impacted by healthcare disruption during the COVID-19 pandemic, as some emerging evidence suggests. ${ }^{12,13}$

Harnessing multiple longitudinal studies allows inequalities to be studied in detail by improving statistical power and allows consistency of findings to be investigated. We therefore aimed to investigate inequalities in healthcare disruption during the COVID-19 pandemic in 12 populationbased longitudinal studies, to help inform targeting of policy responses as we move out of the acute phase of the pandemic. In particular, we investigate healthcare disruptions (including prescription or medication access, procedures or surgery, clinical appointments) by sex, age, ethnicity, education, and occupational social class and we explore whether associations differ by age, or for those who have been recommended to 'shield' due to clinical vulnerability. 
medRxiv preprint doi: https://doi.org/10.1101/2021.06.08.21258546; this version posted June 12, 2021. The copyright holder for this preprint (which was not certified by peer review) is the author/funder, who has granted medRxiv a license to display the preprint in perpetuity.

It is made available under a CC-BY 4.0 International license .

\section{Methods}

\section{Design}

The UK National Core Studies - Longitudinal Health and Wellbeing programme aims to draw together data from multiple UK population-based longitudinal studies to answer questions relevant to the pandemic response. By coordinating analyses within each study and statistically pooling results in a meta-analysis, we can provide robust evidence to understand how the pandemic has impacted population health and support efforts to mitigate its health effects going forward.

\section{Participants}

Data here were from 12 UK population studies which had conducted surveys both before and during the COVID-19 pandemic. Details of the design, sample frames, current age range, timing of the COVID-19 surveys, response rates, and analytical sample size are available in Supplementary Table S1. Ethics statement and data access details can be found in Supplementary Table S2.

Six of these studies were age homogenous birth cohorts (where all individuals were of similar age within each cohort): the Millennium Cohort Study (MCS) $;{ }^{14}$ the Avon Longitudinal Study of Parents and Children (ALSPAC-G1); ${ }^{15}$ Next Steps (NS); ${ }^{16}$ the 1970 British Cohort Study (BCS); ${ }^{17}$ the National Child Development Study (NCDS) $;^{18}$ and the National Survey of Health and Development (NSHD). ${ }^{19,20}$ Six further age heterogeneous studies (each covering a range of age groups) were included: the Born in Bradford study (BIB); ${ }^{21,22}$ Understanding Society (USOC) ${ }^{23}$ Generation Scotland: the Scottish Family Health Study (GS); ${ }^{24}$ the parents of the ALSPAC-G1 cohort which we refer to as ALSPAC-G0; ${ }^{25}$ the UK Adult Twin Registry (TwinsUK); ${ }^{26,27}$ and the English Longitudinal Study of Ageing (ELSA). ${ }^{28}$ Analytical samples were defined within each study based on those who had recorded at least one healthcare disruption outcome in a COVID-19 survey and had valid data on a minimum set of covariates (sex, ethnicity, and age where relevant). Most studies were weighted to be representative of their target populations accounting for differential non-response. ${ }^{20,29,30}$ Weights were not available for BIB or TwinsUK. Studies were ordered for presentation by age of sample (youngest to oldest), with the age homogenous cohorts first, followed by the age heterogenous studies.

\section{Measures}

Below we describe the overall approach to measuring each variable in the analysis. Full details of the questions and coding used within each cohort are available in Supplementary File 1.

\section{Outcomes}

We assessed self-reported disruptions to: prescriptions or medication access; procedures or surgery; and appointments (e.g., with a GP or outpatient services); and a combined variable indicating disruptions to any of the afore-mentioned. Any deviation from planned/existing treatment was coded 
medRxiv preprint doi: https://doi.org/10.1101/2021.06.08.21258546; this version posted June 12, 2021. The copyright holder for this preprint (which was not certified by peer review) is the author/funder, who has granted medRxiv a license to display the preprint in perpetuity.

It is made available under a CC-BY 4.0 International license .

as a disruption, regardless of the reason for the disruption. Where multiple pandemic survey waves had been included, we coded for any disruptions reported up to and including the most recent. This meant at least 7 months of follow-up for most studies (GS had five and ELSA four, while ALSPAC had the longest follow-up period at nine months).

\section{Indicators of Inequality}

We assessed inequalities associated with key sociodemographic characteristics, i.e. sex, age, ethnicity, education, and occupational social class. For age, we considered age-groups categorised as: 16-24; $25-34 ; 35-44 ; 45-54 ; 55-64 ; 65-74$; and $75+$ years. Depending on the ethnic variation of each study and on the level of detail available, we examined both a binary (White [including White minorities] vs Ethnic minorities [excluding White minorities]) and a finer categorisation of ethnicity (White, South Asian, Black, Mixed, Other Asian, Other Ethnic Minority). For education we distinguished between degree or equivalent; A-level or equivalent (i.e. post-compulsory schooling qualifications); GCSE or equivalent (i.e. qualifications for completing compulsory schooling); and fewer or no qualifications. We also examined occupational class with the following categories (based on different coding schemes in different studies): Professional/Managerial; Intermediate; Routine/Manual; and Other (which included never/long-term non-employed and, in some studies, respondents who could not be classified elsewhere). Where respondents' education and occupational class were not available, we considered parental education or household social class. For full details, see Supplementary File 1.

\section{Moderators}

We decided a priori to examine modification by age and clinical vulnerability to COVID-19 to see whether inequalities varied by life-stage or were particularly acute for those with higher healthcare needs and at higher risk from COVID-19 harms. For moderation by age, the age-heterogeneous studies split their samples into the age-bands covered, while age homogeneous cohorts were included within the appropriate age bands (see above for banding). In the UK, clinically extremely vulnerable people were advised to stay at home ('shield') during the pandemic. In this paper, shielding status was based on whether respondents reported having received a letter from the NHS advising them to stay at home to protect themselves.

\section{Other variables}

The following covariates were also included where relevant and available within each study: UK Nation (i.e. England, Scotland, Wales, or Northern Ireland); household composition (based on partnership status and whether there were children in the household); and pre-pandemic self-reported health (good vs poor). 
medRxiv preprint doi: https://doi.org/10.1101/2021.06.08.21258546; this version posted June 12, 2021. The copyright holder for this preprint

(which was not certified by peer review) is the author/funder, who has granted medRxiv a license to display the preprint in perpetuity.

It is made available under a CC-BY 4.0 International license .

\section{Analysis}

Within each study, distributions of sociodemographic characteristics and healthcare disruption were examined. Then, each healthcare disruption outcome was regressed on each indicator of inequality (i.e. sex, age, ethnicity, education, and occupational class). Unadjusted associations are included in Supplementary File 2. Since our aim was primarily to describe inequalities, we focus on presenting associations with minimal adjustment only for sex, age, and ethnicity when applicable. To assess whether associations were independent of other related factors, we also provide supplementary results for any healthcare disruption which additionally adjust for: education, occupational class, UK Nation (where appropriate), household composition, and pre-pandemic self-reported health. Moderation by age and shielding status was assessed using stratified models.

Results were then meta-analysed for each outcome for the full sample, and within age and shielding strata. We used a random effects meta-analysis with restricted maximum likelihood. We report heterogeneity using the $\mathrm{I}^{2}$ statistic $(0 \%$ indicates low variation between estimates across studies, while values closer to $100 \%$ indicate greater heterogeneity). Meta-analyses were conducted in Stata 16 $(\mathrm{V} .16) .^{31}$ 
medRxiv preprint doi: https://doi.org/10.1101/2021.06.08.21258546; this version posted June 12, 2021. The copyright holder for this preprint (which was not certified by peer review) is the author/funder, who has granted medRxiv a license to display the preprint in perpetuity.

It is made available under a CC-BY 4.0 International license.

\section{Results}

\section{Descriptive Statistics}

The distribution of demographic and socio-economic characteristics within each study is presented in Table 1. A total of 68,912 participants were included in the coordinated analysis. Participants from BIB were all female, as were the vast majority (89.4\%) from TwinsUK. The mean age ranged from 16 years in BIB and USOC to 90+ years in TwinsUK and ELSA.

Overall, the prevalence of any healthcare disruption ranged from $6.4 \%$ in TwinsUK to $31.8 \%$ in USOC (Figure 1). Table 2 shows that disruptions to medical appointments were most common, ranging from $3.5 \%$ (ELSA) to $28.4 \%$ (USOC). This was followed by disruptions in prescriptions or medication access, varying from $1.2 \%$ (BIB) to $10.4 \%$ (GS). Disruptions to procedures or surgery were least common ranging from $0.7 \%$ (MCS) to $16.8 \%$ (ELSA).

$<$ Table 1 and 2 about here>

\section{Sex and healthcare disruptions}

Across all studies females were generally more likely to report any healthcare disruptions than males (Supplementary Table S3 for details).

Pooled results from the meta-analysis demonstrate that females had increased odds of any healthcare disruption compared with males (OR: 1.27 [95\%CI: 1.15,1.40]; I I $=54 \%$, figure 2, supplementary file 2). Similar associations were observed for disruptions to appointments (OR: 1.33 [95\%CI: 1.17,1.52]; $\mathrm{I}^{2}=60 \%$ ). The association between sex and the less prevalent disruptions to procedures and medications crossed the null (Supplementary File 2 and Figure 2).

When stratified by age, the odds of having any healthcare disruption for females was highest among 16-24-year-olds (OR: 2.22 [95\% CI 1.63, 3.02]; I I $=0 \%$, Supplementary Table S4). An association between sex and healthcare disruption was observed up to age 54 years but there were no clear associations among those aged 55 years and above. In both the shielding and non-shielding groups, females were more likely to report healthcare disruption (Supplementary Table S5).

$<$ Figure 1 and 2 about here>

\section{Age and healthcare disruptions}

A higher prevalence of having any healthcare disruption was observed among older participants of the national birth cohorts where the same questionnaire was used (Figure 1). This age difference was also observed among the ALSPAC studies and for other age-heterogenous studies as seen in Supplementary Table S3.

The meta-analysis of age-heterogenous studies were supportive of age differences for any healthcare disruptions e.g., OR: 1.39 [1.13,1.72]; $I^{2}=77 \%$ for 65-75y vs 45-54y (Figure 3, Supplementary File 2). Disruptions seemed less likely in younger age groups and more likely among older age groups, 
medRxiv preprint doi: https://doi.org/10.1101/2021.06.08.21258546; this version posted June 12, 2021. The copyright holder for this preprint (which was not certified by peer review) is the author/funder, who has granted medRxiv a license to display the preprint in perpetuity.

It is made available under a CC-BY 4.0 International license .

though some estimates cross the null and had high heterogeneity, which may be because of few studies in specific age categories (Figure 3, Supplementary File 2). Associations for disruptions to medical appointments and procedures or surgery showed these age differences more clearly (Figure 3, Supplementary File 2).

Associations with age and any healthcare disruption were clearest among those not shielding. For those who were shielding, confidence intervals were wide and over-lapped both the null and the estimates from the non-shielding population (Supplementary Table S5). The magnitude for the association of healthcare disruption among 75-year-olds and above vs 45-54 year olds was higher among the non-shielding group (OR: 1.61 [95\%CI: 1.17,2.22]; $\mathrm{I}^{2}=79 \%$ ) compared with the shielding group (OR: 0.83 [95\%CI:0.51,1.37; $\mathrm{I}^{2}=33 \%$ Supplementary Table S5).

<Figure 3 about here>

\section{Ethnicity and healthcare disruptions}

Among the studies that had an ethnically diverse sample, between $7.8 \%$ (BIB) and $31.9 \%$ (USOC) of the White groups reported healthcare disruption. Between $8.3 \%$ (TWINSUK) and 23.6\% (GS) of Ethnic minority groups reported having any healthcare disruption (Supplementary Table S3).

In meta-analysis, Ethnic minorities compared to White groups had increased odds of any healthcare disruption (OR: 1.19 [1.05,1.35]; $\mathrm{I}^{2}=0 \%$, Figure 4 and Supplementary File 2). This association was less clear for specific domains of healthcare disruption (Figure 4, Supplementary File 2). Among the studies that had a finer categorisation of ethnicity, only the Black ethnic groups had clearly raised odds for any healthcare disruption compared with White groups (OR: 1.38 [1.03,1.84]; $\mathrm{I}^{2}=0 \%$ ). Associations with healthcare disruption were less evident for other ethnic groups but were imprecisely estimated (Figure 4, Supplementary File 2).

Associations between ethnicity and any healthcare disruption were not evident within many age bands, though this may simply be due to low power as confidence intervals were wide (Supplementary Table S4). The clearest associations with Ethnic minority groups were within the 3544- and 45-74-year age ranges (OR:1.31 [1.01,1.71]; $\mathrm{I}^{2}=0 \%$ and OR:1.61 [1.16,2.22]; $\mathrm{I}^{2}=0 \%$ ). The mixed ethnicity group were also at particular risk for disruption in the 16-24-year age range too (OR:2.50 [1.25,5.02]; $\mathrm{I}^{2}=0 \%$ ). The magnitude for the association between any healthcare disruption among Ethnic minority groups vs. White groups was higher among those who were shielding (OR: 1.56[1.01 to 2.39]; compared to OR: $1.06[0.86$ to 1.31 ] for non-shielding). This observation was consistent across more granular ethnicity categories, but confidence intervals were wide (Supplementary Table S5).

\footnotetext{
<Figure 4 about here>
}

\section{Education and healthcare disruptions}


medRxiv preprint doi: https://doi.org/10.1101/2021.06.08.21258546; this version posted June 12, 2021. The copyright holder for this preprint (which was not certified by peer review) is the author/funder, who has granted medRxiv a license to display the preprint in perpetuity.

It is made available under a CC-BY 4.0 International license .

There was no clear pattern in the prevalence of healthcare disruption across education levels. For example, in USOC $29.7 \%$ of those with any healthcare disruption had a degree or equivalent and $39 \%$ had no school-leaving qualifications. In TWINSUK $9.9 \%$ of those with any healthcare disruption had a degree or equivalent and $6.1 \%$ had no school-leaving (Supplementary Table S3).

In meta-analysis, we did not observe clear associations between education level and healthcare disruption, other than that those without school-leaving qualifications had raised odds of disruptions to procedures or surgery (OR: $1.26[1.11,1.44] ; \mathrm{I}^{2}=0 \%$; Supplementary File 2 and Figure 5). Associations for not having school-leaving qualifications were particularly evident in the 45-74-year age range but had wide confidence intervals at other ages (Supplementary Table S4). We did not observe differences by shielding status (Supplementary Table S5).

\section{$<$ Figure 5 about here>}

\section{Occupational class and healthcare disruptions}

The prevalence of any healthcare disruption ranged between $9.7 \%$ (BIB) and 25.7\% (USOC) among the Professional/Managerial social class and between 9.3\% (BIB) and $27.6 \%$ (USOC) for the Manual/Routine social class (Supplementary Table S3).

Results from meta-analysis show that those in a more disadvantaged occupational class were more likely to report any healthcare disruptions (e.g., OR: 1.17 [95\%CI: $1.08,1.27] ; \mathrm{I}^{2}=0 \%$ for Manual/Routine compared with Professional/Managerial, Figure 6, Supplementary File 2). The OR was greatest for the non-employed occupational class category (OR: 1.51 [95\%CI: 1.12,2.40]), however the $\mathrm{I}^{2}$ was also large (80\%). This implies considerable between study heterogeneity, though two of the three individual studies (MCS and ELSA) that did not show clear associations for this category were at the extremes of the age range considered. Similar associations were seen for domains of healthcare disruption, with the largest inequalities seen for access to medications.

The associations with occupational class for both routine/manual occupations and long-term nonemployment were most clearly evident from ages 25-64, i.e., primarily among working age participants (Supplementary Table S4). Associations with occupational class were clearest among those not shielding. Among those who were shielding the associations with occupational class were less evident, but confidence intervals were wide and over-lapped both the null and the estimates from the non-shielding population (Supplementary Table S5).

$<$ Figure 6 about here>

\section{Further Adjustment}

The above associations for sex, age and long-term non-employment were largely robust to further adjustment for education, occupational class, UK Nation (where appropriate), household composition, and pre-pandemic self-reported health (see Supplementary File 2). 
medRxiv preprint doi: https://doi.org/10.1101/2021.06.08.21258546; this version posted June 12, 2021. The copyright holder for this preprint (which was not certified by peer review) is the author/funder, who has granted medRxiv a license to display the preprint in perpetuity.

It is made available under a CC-BY 4.0 International license.

\section{Discussion}

Our study demonstrates marked inequalities in healthcare disruption during the COVID-19 pandemic by harnessing data from $12 \mathrm{UK}$ longitudinal studies. Females were more likely to report healthcare disruptions than males, especially at younger ages ( $<55$ years). This inequality was observed for each healthcare disruption type including prescription medication, procedures or surgery, and appointments as well as a combined measure for any of these disruptions. Older adults were especially likely to report disruptions to medical appointments and procedures and surgeries compared to their younger counterparts. Ethnic minority (excluding White minorities) groups were more likely to report healthcare disruption compared to White (including White minorities) groups. Furthermore, when stratifying results by shielding status, the magnitude for the association between any healthcare disruption among Ethnic minority groups (compared to White groups) was higher among those who were shielding. In studies where a finer breakdown of ethnicity was possible, Black ethnic minority groups had the most clearly increased odds of disruption compared to White ethnic groups. Occupational class was also found to be associated with healthcare disruption with those in a routine/manual occupation or other (which included never/long-term non-employed) being more likely to experience healthcare disruption than those in a managerial/professional occupation, and this inequality appeared to be concentrated within working ages (i.e. 25-64 years). No clear association between education and healthcare disruption was found in the main, age or shielding status stratified analyses.

The direct burden of COVID-19 on health services across the globe has been colossal and remains so in some countries, with prioritisation of COVID-19 patients, leaving less capacity and resources for non-COVID-19 healthcare. Furthermore, associated repeated lockdown measures are also likely to decrease healthcare access and availability with a decrease in the number of people attending A\&E services, ${ }^{4}$ and reports of difficulties accessing medication. ${ }^{8}$

Our findings are consistent with current evidence from a smaller sub-set of the studies examined here suggesting that females are more likely to experience disruption to planned surgery, medical procedures, or other medical appointments during lockdown. ${ }^{12}$

Furthermore, our results show that older adults were more likely to report healthcare disruption as compared to their younger counterparts, especially disruptions to medical appointments and planned procedures or surgeries. This finding is consistent with current UK evidence indicating that older adults experience more delays and disruption to health services. ${ }^{32-35}$

Black ethnic minority groups were also found to be at increased risk of healthcare disruption compared to white ethnic groups - an issue of particular concern given pre-pandemic ethnic inequalities in healthcare. ${ }^{36}$ The inequalities by occupational class we found are consistent with prior evidence of socioeconomic healthcare inequalities reported in the UK in the past decade, ${ }^{37}$ and highlight that these have still been present in the COVID-19 pandemic. Associations with 
medRxiv preprint doi: https://doi.org/10.1101/2021.06.08.21258546; this version posted June 12, 2021. The copyright holder for this preprint (which was not certified by peer review) is the author/funder, who has granted medRxiv a license to display the preprint in perpetuity.

It is made available under a CC-BY 4.0 International license .

occupational class were clearer than those for education, which is also an indicator of socioeconomic position but may have been a more distal influence.

\section{Strengths and limitations}

The analysis brings together data from 12 longitudinal studies with rich and sensitive information on healthcare disruption. This study is strengthened by the coordinated investigation in multiple longitudinal studies with differing study designs, different target populations, and varying selection and attrition processes. Moreover, the use of multiple studies increased statistical power to look at subpopulations such as ethnic minority groups across cohorts and allowed for greater examination of how inequalities were patterned by age. Our novel approach to coordinated analyses harnessing multiple datasets therefore allowed research questions to be addressed which would not otherwise be possible.

Differences between studies in a range of factors including measurement of healthcare disruption, timing of surveys, design, response rates, and differential selection into the COVID-19 sweeps are potentially responsible for heterogeneity in estimates. However, despite this heterogeneity, the key findings were consistent across most datasets. Furthermore, this heterogeneity can be informative, for example, by virtue of mixing age-specific and age range studies, we identified that sex inequalities were stronger at younger ages, and inequalities by occupational class were concentrated within working ages. The definition of healthcare disruption used may also have contained a range of disruptions of greater or lesser severity, and there may have been further inequalities in the severity of disruptions experienced.

We have focused on our aim of identifying who experienced greater disruptions in healthcare, rather than on adjustment for confounders to estimate causal effects of the exposures in question. ${ }^{38}$ Nevertheless, many of the associations we observed were robust to adjustment for a wider range of related variables, but bias due to residual confounding cannot be ruled out. Importantly, we did not condition our analyses on healthcare need. Many of the inequalities we observed for healthcare disruptions may be due to inequalities in health, with those who have greater health needs being more likely to require healthcare that could be disrupted. Accounting for differences in need could have masked inequalities in healthcare disruptions that are caused by inequalities in health and could have made it less clear which groups have been more likely to experience disruption during the pandemic. Restricting analyses to those who needed care could also induce bias if there were unmeasured determinants of both need and disruption. ${ }^{39}$ Nevertheless, another study of the USOC data analysed here that did restrict analyses to those needing care still found income-related inequalities in healthcare disruption, and most of the associations we observed were robust to adjustment for prepandemic self-assessed health. ${ }^{40}$ 


\section{Impact of healthcare disruption}

Disadvantaged groups such as females, older adults, Black ethnic minority groups, and those in routine/manual occupations have had elevated odds of healthcare disruption in the first 8-10 months of the COVID-19 pandemic. Delays and disruptions to treatment could have ongoing implications for patients' physical and mental health. ${ }^{41}$ Action is needed to remedy these inequalities, and efforts to ensure continuity of care during pandemic-related disruptions may need to be more clearly targeted to those who most need that care. As healthcare access resumes, given the forgone delays in treatments and the subsequent backlog of postponed surgeries, ${ }^{42}$ these groups may require prioritised support to address unmet needs experienced during the pandemic.

\section{Conclusion}

There have been clear inequalities in disruptions to healthcare during the COVID-19 pandemic in the UK. Females (especially at younger ages), older adults, ethnic minorities, and those in disadvantaged occupational classes (especially at working ages) have been more likely to experience healthcare disruptions. These are groups who usually experience worse health, so disruptions related to COVID19 have clear potential to maintain or even exacerbate existing health inequalities. 
medRxiv preprint doi: https://doi.org/10.1101/2021.06.08.21258546; this version posted June 12, 2021. The copyright holder for this preprint (which was not certified by peer review) is the author/funder, who has granted medRxiv a license to display the preprint in perpetuity.

It is made available under a CC-BY 4.0 International license .

\section{References}

1. Boserup B, Mckenney M, Elkbuli A. The impact of the COVID-19 pandemic on emergency department visits and patient safety in the United States. Am J Emerg Med. 2020;38(January):1732-1736.

2. Vuma CD, Manganyi J, Wilson K, Rees D. The Effect on Fit of Multiple Consecutive Donning and Doffing of N95 Filtering Facepiece Respirators. Ann Work Expo Heal. 2019;63(8):930-936. doi:10.1093/annweh/wxz060

3. Salerno R, Conti CB, De Silvestri A, Campbell Davies SE, Mezzina N, Ardizzone S. The impact of covid-19 pandemic on urgent endoscopy in Italy: a nation-wide multicenter study. Scand J Gastroenterol. 2020;55(7):870-876. doi:10.1080/00365521.2020.1782466

4. Kelly E, Firth Z. How is COVID-19 changing the use of emergency care by region? The Health Foundation. Published 2020. https://www.health.org.uk/news-and-comment/charts-andinfographics/how-is-covid-19-changing-the-use-of-emergency-care-by-region

5. Lazzerini M, Barbi E, Apicella A, Marchetti F, Cardinale F, Trobia G. Delayed access or provision of care in Italy resulting from fear of COVID-19. Lancet Child Adolesc Heal. 2020;4(5):e10-e11. doi:10.1016/S2352-4642(20)30108-5

6. Association BM. Pressure points in the NHS. British Medical Association. Published 2021. https://www.bma.org.uk/advice-and-support/nhs-delivery-and-workforce/pressures/pressurepoints-in-the-nhs

7. Cheong JLY, Goh ZHK, Marras C, Tanner CM, Kasten M, Noyce AJ. The Impact of COVID19 on Access to Parkinson's Disease Medication. Mov Disord. 2020;35(12):2129-2133. doi: $10.1002 / \mathrm{mds} .28293$

8. Maldonado D, Tu E, Mahmood S, et al. Medication access difficulty and COVID $\square$ related distress are associated with disease flares in rheumatology patients during the COVID $\square 19$ pandemic. Arthritis Care Res (Hoboken). Published online 2020:0-3. doi:10.1002/acr.24531

9. Bleich SN, Jarlenski MP, Bell CN, Laveist TA. Health inequalities: Trends, progress, and policy. Annu Rev Public Health. 2012;33:7-40. doi:10.1146/annurev-publhealth-031811124658

10. Immergut EM, Schneider SM. Is it unfair for the affluent to be able to purchase "better" healthcare? Existential standards and institutional norms in healthcare attitudes across 28 countries. Soc Sci Med. 2020;267(June):113146. doi:10.1016/j.socscimed.2020.113146

11. Tudor Hart J. the Inverse Care Law. Lancet. 1971;297(7696):405-412. doi:10.1016/S01406736(71)92410-X

12. Topriceanu CC, Wong A, Moon JC, et al. Evaluating access to health and care services during lockdown by the COVID-19 survey in five UK national longitudinal studies. BMJ Open. 2021;11(3). doi:10.1136/bmjopen-2020-045813

13. Institute for Fiscal Studies. COVID-19 and disruptions to the health and social care of older people in England. Published online 2020:1-21.

14. Joshi HE, Fitzsimons E. The UK Millennium Cohort Study: the making of a multi- purpose resource for social science and policy in the UK. Longit Life Course Stud. 2016;7(4):409-430. doi:10.14301/llcs.v7i4.416

15. Boyd A, Golding J, Macleod J, et al. Cohort profile: The 'Children of the 90s'-The index offspring of the avon longitudinal study of parents and children. Int J Epidemiol.

2013;42(1):111-127. doi:10.1093/ije/dys064

16. Calderwood L, Sanchez C. Next Steps ( formerly known as the Longitudinal Study of Young 
medRxiv preprint doi: https://doi.org/10.1101/2021.06.08.21258546; this version posted June 12, 2021. The copyright holder for this preprint (which was not certified by peer review) is the author/funder, who has granted medRxiv a license to display the preprint in perpetuity.

It is made available under a CC-BY 4.0 International license.

People in England ). Published online 2016:2-4.

17. Elliott J, Shepherd P. Cohort profile: 1970 British Birth Cohort (BCS70). Int J Epidemiol. 2006;35(4):836-843. doi:10.1093/ije/dyl174

18. Power C, Elliott J. Cohort profile: 1958 British birth cohort (National Child Development Study). Int J Epidemiol. 2006;35(1):34-41. doi:10.1093/ije/dyi183

19. Wadsworth M, Kuh D, Richards M, Hardy R. Cohort profile: The 1946 National Birth Cohort (MRC National Survey of Health and Development). Int J Epidemiol. 2006;35(1):49-54. doi:10.1093/ije/dyi201

20. Brown M, Goodman A, Peters A, et al. COVID-19 Survey in Five National Longitudinal Studies: Wave 1 User Guide (Version 1). UCL Cent Longitud Stud MRC Unit Lifelong Heal Ageing London, UK. 2020;(December):1-62. https://cls.ucl.ac.uk/wpcontent/uploads/2021/01/UCL-Cohorts-COVID-19-Survey-user-guide.pdf

21. Wright J, Small N, Raynor P, et al. Cohort profile: The born in bradford multi-ethnic family cohort study. Int J Epidemiol. 2013;42(4):978-991. doi:10.1093/ije/dys112

22. Dickerson J, Bird PK, McEachan RRC, et al. Born in Bradford's Better Start: An experimental birth cohort study to evaluate the impact of early life interventions. BMC Public Health. 2016;16(1):1-14. doi:10.1186/s12889-016-3318-0

23. University of Essex, Institute for Social and Economic Research, NatCen Social Research KP. Understanding Society: Waves 1-9, 2009-2019 and Harmonised BHPS: Waves 1-18, 19912009. [data collection].

24. Smith BH, Campbell A, Linksted P, et al. Cohort profile: Generation scotland: Scottish family health study (GS: SFHS). The study, its participants and their potential for genetic research on health and illness. Int J Epidemiol. 2013;42(3):689-700. doi:10.1093/ije/dys084

25. Fraser A, Macdonald-wallis C, Tilling K, et al. Cohort Profile $\square$ : The Avon Longitudinal Study of Parents and Children $\square$ : ALSPAC mothers cohort. 2013;(April 2012):97-110. doi:10.1093/ije/dys066

26. Suthahar A, Sharma P, Hart D, et al. TwinsUK COVID-19 personal experience questionnaire ( CoPE ): wave 1 data capture April-May 2020 [ version $1 \square$; peer review $\square$ : awaiting peer review ]. 2021;(May 2020):1-10.

27. Verdi S, Abbasian G, Bowyer RCE, et al. TwinsUK: The UK Adult Twin Registry Update. Twin Res Hum Genet. 2019;(May 2007):1-7. doi:10.1017/thg.2019.65

28. Steptoe A, Breeze E, Banks J, Nazroo J. Cohort profile: The English Longitudinal Study of Ageing. Int J Epidemiol. 2013;42(6):1640-1648. doi:10.1093/ije/dys168

29. Addario G, Dangerfield P, Hussey D, Pacchiotti B, Wood M. Adapting Fieldwork during the COVID-19 Outbreak A Methodological Overview of the ELSA COVID-19 Substudy (Wave 1).; 2020.

30. Institute for Social and Economic Research. Understanding Society COVID-19 User Guide.; 2021. doi:10.1007/978-1-349-15392-3

31. Press S. Stata Statistical Software: Release 16. StataCorp LLC.

32. Mann DM, Chen J, Chunara R, Testa PA, Nov O. COVID-19 transforms health care through telemedicine: Evidence from the field. J Am Med Informatics Assoc. 2020;27(7):1132-1135. doi:10.1093/jamia/ocaa072

33. Beaunoyer E, Dupéré S, Guitton MJ. COVID-19 and digital inequalities: Reciprocal impacts and mitigation strategies. Comput Human Behav. 2020;111(April). 
medRxiv preprint doi: https://doi.org/10.1101/2021.06.08.21258546; this version posted June 12, 2021. The copyright holder for this preprint (which was not certified by peer review) is the author/funder, who has granted medRxiv a license to display the preprint in perpetuity.

It is made available under a CC-BY 4.0 International license.

doi:10.1016/j.chb.2020.106424

34. Crawford A, Serhal E. Digital health equity and COVID-19: The innovation curve cannot reinforce the social gradient of health. J Med Internet Res. 2020;22(6):1-5. doi:10.2196/19361

35. Kojima G, Liljas AEM, Iliffe S. Frailty syndrome: Implications and challenges for health care policy. Risk Manag Healthc Policy. 2019;12:23-30. doi:10.2147/RMHP.S168750

36. Katikireddi SV, Cezard G, Bhopal RS, et al. Assessment of health care, hospital admissions, and mortality by ethnicity: population-based cohort study of health-system performance in Scotland. Lancet Public Heal. 2018;3(5):e226-e236. doi:10.1016/S2468-2667(18)30068-9

37. Cookson R, Propper C, Asaria M, Raine R. Socio-Economic Inequalities in Health Care in England. Fisc Stud. 2016;37(3-4):371-403. doi:10.1111/j.1475-5890.2016.12109

38. Conroy S, Murray EJ. Let the question determine the methods: descriptive epidemiology done right. Br J Cancer. 2020;123(9):1351-1352. doi:10.1038/s41416-020-1019-Z

39. Cole SR, Platt RW, Schisterman EF, et al. Illustrating bias due to conditioning on a collider. Int J Epidemiol. 2010;39(2):417-420. doi:10.1093/ije/dyp334

40. Davillas A, Jones AM. Unmet health care need and income $\square$ Related horizontal equity in use ofhealth care during the COVID $\square 19$ pandemic. Health Econ. 2021;(December 2020):1-6. doi:10.1002/hec. 4282

41. Barach P, Fisher SD. Disruption of healthcare: Will the COVID pandemic worsen non-COVID outcomes and disease outbreaks? Prog Pediatr Cardiol. 2020;(January).

42. Nepogodiev D, Omar OM, Glasbey JC, et al. Elective surgery cancellations due to the COVID-19 pandemic: global predictive modelling to inform surgical recovery plans. $B r J$ Surg. 2020;107(11):1440-1449. doi:10.1002/bjs.11746 
Table 1. Percent (and N) distribution of demographic and socio-economic characteristics by study

\begin{tabular}{|c|c|c|c|c|c|c|c|c|c|c|c|c|c|}
\hline \multirow{2}{*}{\multicolumn{2}{|c|}{\begin{tabular}{|l} 
Total analytic $\mathbf{N}$ \\
\end{tabular}}} & $M C S$ & $\begin{array}{c}A L S P A C \\
G 1\end{array}$ & $N S$ & BCS70 & $N C D S$ & NSHD & $B I B$ & USOC & $G S$ & $\begin{array}{l}A L S P A C \\
\text { G0 }\end{array}$ & TWINS UK & $E L S A$ \\
\hline & & 3,147 & 3,430 & 3,311 & 5,175 & 5,747 & 1,569 & 1,726 & 13,253 & 17,139 & 3,625 & 4,282 & 6,508 \\
\hline \multicolumn{2}{|c|}{ Female } & $\begin{array}{c}65.0 \\
(2,045)\end{array}$ & $\begin{array}{c}65.3 \\
(2,240)\end{array}$ & $\begin{array}{c}64.8 \\
(2,145)\end{array}$ & $\begin{array}{c}57.9 \\
(2,994)\end{array}$ & $\begin{array}{c}53.7 \\
(3,086)\end{array}$ & $\begin{array}{l}52.6 \\
(825)\end{array}$ & $\begin{array}{c}100.0 \\
(1,726)\end{array}$ & $\begin{array}{c}57.9 \\
(7,668)\end{array}$ & $\begin{array}{c}67.0 \\
(11,476)\end{array}$ & $\begin{array}{c}73.1 \\
(2,651)\end{array}$ & $\begin{array}{c}89.4 \\
(3,830)\end{array}$ & $\begin{array}{c}56.3 \\
(3,663)\end{array}$ \\
\hline \multicolumn{2}{|c|}{ Mean Age in 2020 (range) } & $\begin{array}{c}19.5 \\
(18.7-20.1)\end{array}$ & $\begin{array}{c}28.4 \\
(27-29)\end{array}$ & $\begin{array}{c}30.6 \\
(29.9-31.4)\end{array}$ & $\begin{array}{c}50.5 \\
(50.4-50.6)\end{array}$ & $\begin{array}{c}62.6 \\
(62.5-62.7)\end{array}$ & 74 & $\begin{array}{c}37.5 \\
(16-54)\end{array}$ & $\begin{array}{c}51.1 \\
(16-96.2)\end{array}$ & $\begin{array}{c}57.0 \\
(18-100)\end{array}$ & $\begin{array}{c}59.4 \\
(45-89)\end{array}$ & $\begin{array}{c}61.2 \\
(22-96)\end{array}$ & $\begin{array}{c}69.3 \\
(52-90+)\end{array}$ \\
\hline \multirow{7}{*}{ 总 } & White & $\begin{array}{c}86.1 \\
(2,708)\end{array}$ & $\begin{array}{c}98.4 \\
(3,330)\end{array}$ & $\begin{array}{c}74.6 \\
(2,470)\end{array}$ & NA & NA & NA & $37.8(653)$ & $\begin{array}{c}98.3 \\
(16,843)\end{array}$ & $\begin{array}{c}87.2 \\
(11,561)\end{array}$ & $\begin{array}{c}98.4 \\
(3,567)\end{array}$ & $\begin{array}{c}97.1 \\
(4,156)\end{array}$ & $\begin{array}{c}95.9 \\
(6,239)\end{array}$ \\
\hline & South Asian & $7.6(240)$ & NA & $15.0(496)$ & NA & NA & NA & $56.1(968)$ & $0.4(70)$ & $6.7(885)$ & NA & $0.7(28)$ & $2.1(135)$ \\
\hline & East Asian & $1.0(30)$ & NA & NA & NA & NA & $\overline{\mathrm{NA}}$ & NA & $0.3(51)$ & $1.2(155)$ & NA & $0.1(3)$ & NA \\
\hline & Black & $2.6(83)$ & NA & $3.8(127)$ & NA & NA & NA & $2.0(34)$ & $0.1(21)$ & $2.5(334)$ & NA & $1.1(45)$ & $1.2(75)$ \\
\hline & Mixed & $2.4(76)$ & NA & $4.6(152)$ & NA & NA & NA & $1.4(24)$ & $0.6(105)$ & $1.8(241)$ & NA & $0.9(38)$ & $0.9(59)$ \\
\hline & Other & $0.3(10)$ & NA & $2.0(66)$ & NA & NA & NA & $2.7(47)$ & $0.3(49)$ & $0.6(77)$ & NA & $0.3(12)$ & NA \\
\hline & $\begin{array}{l}\text { All ethnic } \\
\text { minorities }\end{array}$ & 13.9 (439) & $2.9(100)$ & $25.4(841)$ & NA & NA & NA & $62.2(1,073)$ & $1.3(226)$ & $12.8(1692)$ & $1.6(58)$ & $2.9(126)$ & $4.1(269)$ \\
\hline \multirow{4}{*}{ 氖 } & $\begin{array}{l}\text { Higher Education } \\
\text { or Degree }\end{array}$ & $\begin{array}{c}55.9 \\
(1,758)\end{array}$ & $\begin{array}{l}29.0 \\
(994)\end{array}$ & $\begin{array}{c}48.9 \\
(1,620)\end{array}$ & $\begin{array}{c}46.6 \\
(2,411)\end{array}$ & $\begin{array}{c}46.0 \\
(2,646)\end{array}$ & $\begin{array}{l}29.0 \\
(994)\end{array}$ & $35.1(556)$ & $\begin{array}{c}50.7 \\
(8,602)\end{array}$ & $\begin{array}{c}47.1 \\
(6,238)\end{array}$ & $\begin{array}{c}29.7 \\
(1,075)\end{array}$ & $\begin{array}{c}55.7 \\
(2,386)\end{array}$ & $\begin{array}{c}25.6 \\
(1,666)\end{array}$ \\
\hline & $\begin{array}{l}\text { A-level } \\
\text { or equivalent }\end{array}$ & $\begin{array}{c}15.0 \\
(473) \\
\end{array}$ & $\begin{array}{c}35.1 \\
(1,203) \\
\end{array}$ & $\begin{array}{c}23.4 \\
(773)\end{array}$ & $\begin{array}{c}14.2 \\
(733) \\
\end{array}$ & $\begin{array}{c}18.0 \\
(1,034) \\
\end{array}$ & $\begin{array}{c}35.1 \\
(1203) \\
\end{array}$ & $17.2(273)$ & $\begin{array}{c}35.9 \\
(6,096) \\
\end{array}$ & $\begin{array}{c}11.6 \\
(1,543) \\
\end{array}$ & $\begin{array}{c}29.7 \\
(1,078) \\
\end{array}$ & $\begin{array}{l}11.6 \\
(498) \\
\end{array}$ & $\begin{array}{c}27.6 \\
(1,798) \\
\end{array}$ \\
\hline & $\begin{array}{l}G C S E \\
\text { or equivalent }\end{array}$ & $\begin{array}{c}19.5 \\
(615)\end{array}$ & $\begin{array}{c}26.1 \\
(896)\end{array}$ & $\begin{array}{l}19.0 \\
(628)\end{array}$ & $\begin{array}{c}23.4 \\
(1,209)\end{array}$ & $\begin{array}{c}22.8 \\
(1,311)\end{array}$ & $\begin{array}{l}26.1 \\
(896)\end{array}$ & $22.3(354)$ & $\begin{array}{c}6.2 \\
(1046)\end{array}$ & $\begin{array}{c}25.2 \\
(3,341)\end{array}$ & $\begin{array}{c}30.3 \\
(1,098)\end{array}$ & $\begin{array}{l}20.5 \\
(877)\end{array}$ & $\begin{array}{c}22.3 \\
(1,452)\end{array}$ \\
\hline & $<G C S E$ or none & $\begin{array}{c}9.6 \\
(301)\end{array}$ & $\begin{array}{c}9.83 \\
(337)\end{array}$ & $\begin{array}{c}8.8 \\
(290)\end{array}$ & $\begin{array}{c}15.9 \\
(822)\end{array}$ & $\begin{array}{c}13.2 \\
(756)\end{array}$ & $\begin{array}{c}9.8 \\
(337)\end{array}$ & $25.5(405)$ & $\begin{array}{c}7.2 \\
(1,214)\end{array}$ & $\begin{array}{c}16.1 \\
(2,131)\end{array}$ & $\begin{array}{c}10.3 \\
(374)\end{array}$ & $\begin{array}{c}12.2 \\
(521)\end{array}$ & $\begin{array}{c}24.5 \\
(1,592)\end{array}$ \\
\hline \multirow{4}{*}{ 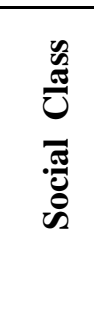 } & $\begin{array}{c}\text { Managerial, Admin, } \\
\text { Professional }\end{array}$ & $\begin{array}{c}51.3 \\
(1,614)\end{array}$ & $\begin{array}{c}18.0 \\
(616)\end{array}$ & $\begin{array}{c}47.6 \\
(1,575)\end{array}$ & $\begin{array}{c}42.7 \\
(2,209)\end{array}$ & $\begin{array}{c}23.0 \\
(1,319)\end{array}$ & $\begin{array}{c}18 \\
(616)\end{array}$ & $31.2(475)$ & $\begin{array}{c}81.0 \\
(10,716)\end{array}$ & $\begin{array}{c}35.0 \\
(4,639)\end{array}$ & $\begin{array}{c}13.4 \\
(486)\end{array}$ & NA & $\begin{array}{c}32.4 \\
(2,111)\end{array}$ \\
\hline & Intermediate & $\begin{array}{c}15.4 \\
(484)\end{array}$ & $\begin{array}{c}46.2 \\
(1,583)\end{array}$ & $\begin{array}{c}18.9 \\
(625)\end{array}$ & $\begin{array}{c}21.1 \\
(1,091)\end{array}$ & $\begin{array}{c}14.9 \\
(856) \\
\end{array}$ & $\begin{array}{c}46.1 \\
(1,583)\end{array}$ & $35.7(545)$ & $\begin{array}{c}14.4 \\
(1,906)\end{array}$ & $\begin{array}{c}17.1 \\
(2,264)\end{array}$ & $\begin{array}{c}41.2 \\
(1,492)\end{array}$ & NA & $\begin{array}{c}23.0 \\
(1,497)\end{array}$ \\
\hline & Manual/Routine & $\begin{array}{c}18.9 \\
(595)\end{array}$ & $\begin{array}{c}35.3 \\
(1,212)\end{array}$ & $\begin{array}{c}15.0 \\
(495)\end{array}$ & $\begin{array}{c}19.5 \\
(1,009)\end{array}$ & $\begin{array}{c}16.5 \\
(948) \\
\end{array}$ & $\begin{array}{c}35.3 \\
(1,212) \\
\end{array}$ & $25.3(386)$ & $\begin{array}{c}4.4 \\
(581) \\
\end{array}$ & $\begin{array}{c}20.1 \\
(2,663)\end{array}$ & $\begin{array}{c}44.6 \\
(1,617)\end{array}$ & NA & $\begin{array}{c}28.2 \\
(1,834)\end{array}$ \\
\hline & Other & $\begin{array}{c}14.4 \\
(454)\end{array}$ & $\begin{array}{c}0.6 \\
(19)\end{array}$ & $\begin{array}{r}18.6 \\
(616) \\
\end{array}$ & $\begin{array}{c}16.7 \\
(866)\end{array}$ & $\begin{array}{c}45.7 \\
(2,624)\end{array}$ & $\begin{array}{c}0.6 \\
(19) \\
\end{array}$ & 7.8 (119) & $\begin{array}{c}0.2 \\
(27) \\
\end{array}$ & $\begin{array}{c}27.8 \\
(3687)\end{array}$ & $\begin{array}{c}0.8 \\
(30) \\
\end{array}$ & NA & $\begin{array}{c}16.4 \\
(1,066)\end{array}$ \\
\hline \multicolumn{2}{|c|}{ Instructed to Shield } & $2.5(79)$ & NA & $3.3(110)$ & $5.2(267)$ & $6.9(393)$ & $\begin{array}{c}8.8 \\
(101)\end{array}$ & $7.6(131)$ & $6.2(825)$ & $7.8(1,332)$ & NA & $5.9(252)$ & $16.3(1,062)$ \\
\hline
\end{tabular}


Sources: MCS (Millennium Cohort Study); ALSPAC G1 (Children of the Avon Longitudinal Study of Parents and Children); NS (Next Steps); BCS 70 (1970 British Cohort Study), NCDS (National Child Development Study); NSHD (National Survey of Health and Development); BIB (Born in Bradford); USOC (Understanding Society); GS (Generation Scotland: the Scottish Family Health Study); ALSPAC G0 (parents of ALSPAC); TWINS UK (UK Adult Twin Registry); ELSA (English Longitudinal Study of Ageing). Notes: Studies are ordered by age homogeneity/heterogeneity and mean age of respondents at the time of the interview. Samples for each study restricted to respondents with non-missing information on healthcare disruptions and valid information on sex, social class, education and (where applicable) age and ethnicity. All information about how data were collected and variables were coded is available in Supplementary File 1. NA = Not available/Info not collected. Unweighted data. 
Table 2. Percent prevalence (and 95\% confidence intervals) of healthcare disruptions during the pandemic, by study

\begin{tabular}{|c|c|c|c|c|c|c|c|c|c|c|c|c|}
\hline & $M C S$ & $\begin{array}{c}\text { ALSPAC } \\
\text { (G1) }\end{array}$ & $N S \square$ & BCS70 & $N C D S$ & NSHD & $B I B$ & USOC & $G S$ & $\begin{array}{c}A L S P A C \\
(G 0) \square\end{array}$ & TWINS UK & $E L S A$ \\
\hline $\begin{array}{l}\text { Prescription/ } \\
\text { medication access }\end{array}$ & $\begin{array}{c}4.0 \\
(2.3-5.5) \\
\end{array}$ & NA & $\begin{array}{c}3.8 \\
(2.3-5.3) \\
\end{array}$ & $\begin{array}{c}3.4 \\
(2.7-4.2) \\
\end{array}$ & $\begin{array}{c}2.4 \\
(1.8-3.0) \\
\end{array}$ & $\begin{array}{c}2.2 \\
(1.3-3.8) \\
\end{array}$ & $\begin{array}{c}1.2 \\
(0.7-1.7) \\
\end{array}$ & $\begin{array}{c}5.5 \\
(5.0-6.1) \\
\end{array}$ & $\begin{array}{c}10.4 \\
(9.9-10.9) \\
\end{array}$ & NA & $\begin{array}{c}2.9 \\
(2.5-3.3) \\
\end{array}$ & $\begin{array}{c}0.8 \\
(0.6-1.2) \\
\end{array}$ \\
\hline Appointments & $\begin{array}{c}6.2 \\
(4.9-7.6)\end{array}$ & $\begin{array}{c}11.7 \\
(10.3-13.2)\end{array}$ & $\begin{array}{c}7.3 \\
(5.6-9.0)\end{array}$ & $\begin{array}{c}10.6 \\
(9.2-12.1)\end{array}$ & $\begin{array}{c}12.1 \\
(10.9-13.3)\end{array}$ & $\begin{array}{c}12.0 \\
(9.3-15.6)\end{array}$ & $\begin{array}{c}8.6 \\
(7.4-10.1)\end{array}$ & $\begin{array}{c}28.4 \\
(27.4-29.4)\end{array}$ & $\begin{array}{c}16.6 \\
(16.0-17.1)\end{array}$ & $\begin{array}{c}14.4 \\
(12.8-16.2)\end{array}$ & NA & $\begin{array}{c}3.5 \\
(2.9-4.1)\end{array}$ \\
\hline
\end{tabular}

Sources: MCS (Millennium Cohort Study); ALSPAC G1 (Children of the Avon Longitudinal Study of Parents and Children); NS (Next Steps); BCS 70 (1970 British Cohort Study), NCDS (National Child Development Study); NSHD (National Survey of Health and Development); BIB (Born in Bradford); USOC (Understanding Society); GS (Generation Scotland: the Scottish Family Health Study); ALSPAC G0 (parents of ALSPAC); TWINS UK (UK Adult Twin Registry); ELSA (English Longitudinal Study of Ageing). Notes: Studies are ordered by age homogeneity/heterogeneity and mean age of respondents at the time of the interview. Samples for each study restricted to respondents with non-missing information on healthcare disruptions and valid information on sex, social class, education and (where applicable) age and ethnicity. All information about how data were collected and variables were coded is available in Supplementary File 1. TWINSUK had an additional question: "Have you experienced healthcare disruption as a result of the COVID-19 pandemic?" This data was also used to derive the 'any healthcare disruption' variable for TWINSUK. NA = Not available/Info not collected. Weighted data where applicable 
medRxiv preprint doi: https://doi.org/10.1101/2021.06.08.21258546; this version posted June 12, 2021. The copyright holder for this preprint

(which was not certified by peer review) is the author/funder, who has granted medRxiv a license to display the preprint in perpetuity.

It is made available under a CC-BY 4.0 International license.

Figure Legends:

Figure 1. Prevalence (and 95\% CIs) of any healthcare disruption by study

Sources: MCS (Millennium Cohort Study); ALSPAC G1 (Children of the Avon Longitudinal Study of Parents and Children); NS (Next Steps); BCS 70 (1970 British Cohort Study), NCDS (National Child Development Study); NSHD (National Survey of Health and Development); BIB (Born in Bradford); USOC (Understanding Society); GS (Generation Scotland: the Scottish Family Health Study); ALSPAC G0 (parents of ALSPAC); TWINS UK (UK Adult Twin Registry); ELSA (English Longitudinal Study of Ageing). Notes: Studies are ordered by age homogeneity/heterogeneity and mean age of respondents at the time of the interview. Samples for each study restricted to respondents with non-missing information on healthcare disruptions and valid information on sex, social class, education and (where applicable) age and ethnicity. All information about how data were collected and variables were coded is available in Supplementary File 1.

Figure 2: Associations between female (compared to male) sex and healthcare disruption. Notes: Adjusted for age and ethnicity where applicable.

Figure 3: Associations between age (compared to 45-54 year olds) and healthcare disruption. Notes: Adjusted for sex and ethnicity where applicable.

Figure 4: Associations between Ethnicity (compared to White groups) and healthcare disruption. Notes: Panels illustrate findings for some larger ethnic groups separately and the final panel presents results for all non-White ethnic minorities combined. Adjusted for age and sex where applicable.

Figure 5: Associations between education (compared to degree level) and healthcare disruption Notes: Adjusted for age, sex and ethnicity where applicable.

Figure 6: Associations between occupational social class (compared to Professional/Managerial) and healthcare disruption. Notes: Adjusted for age, sex and ethnicity where applicable. 


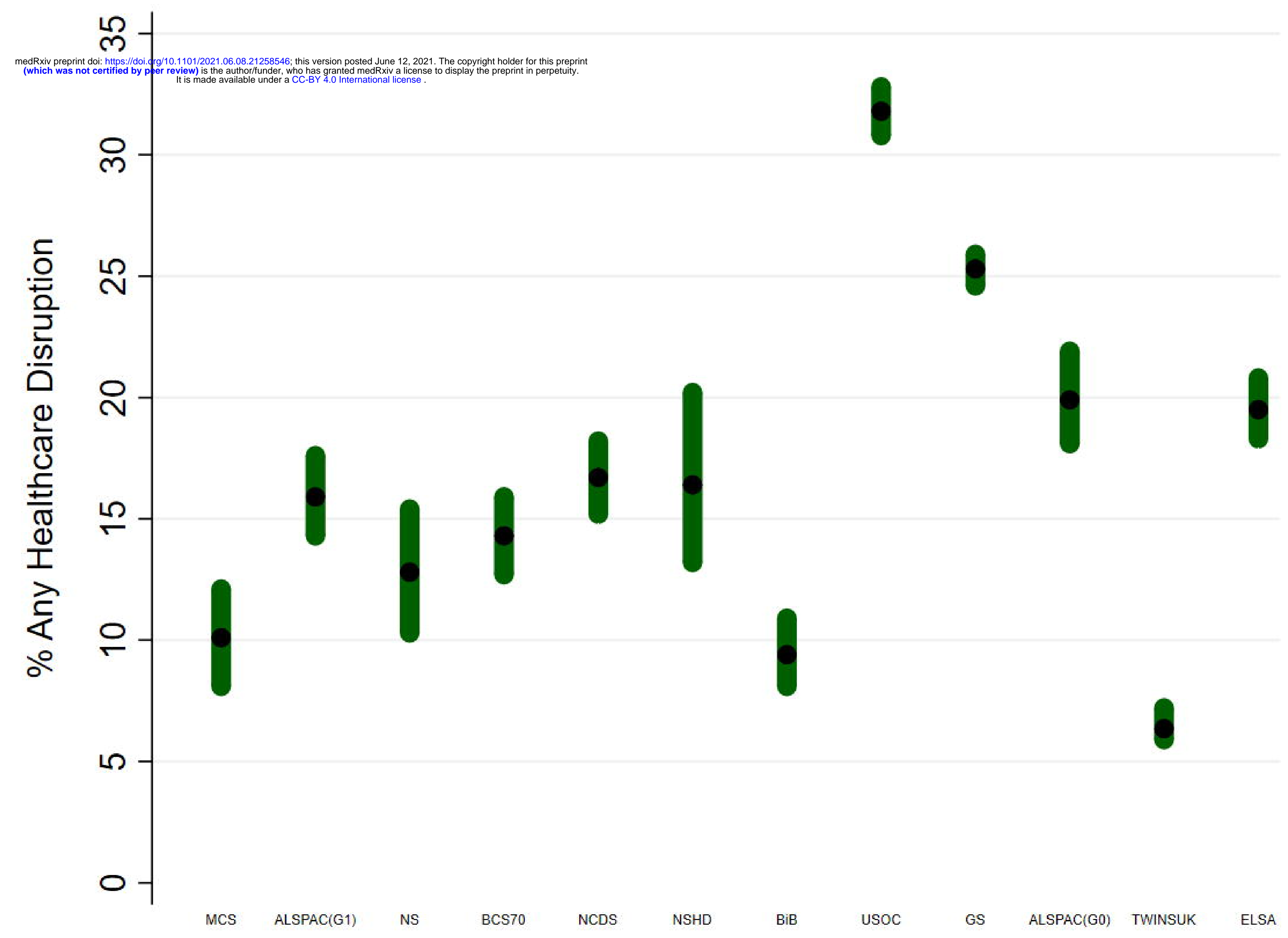




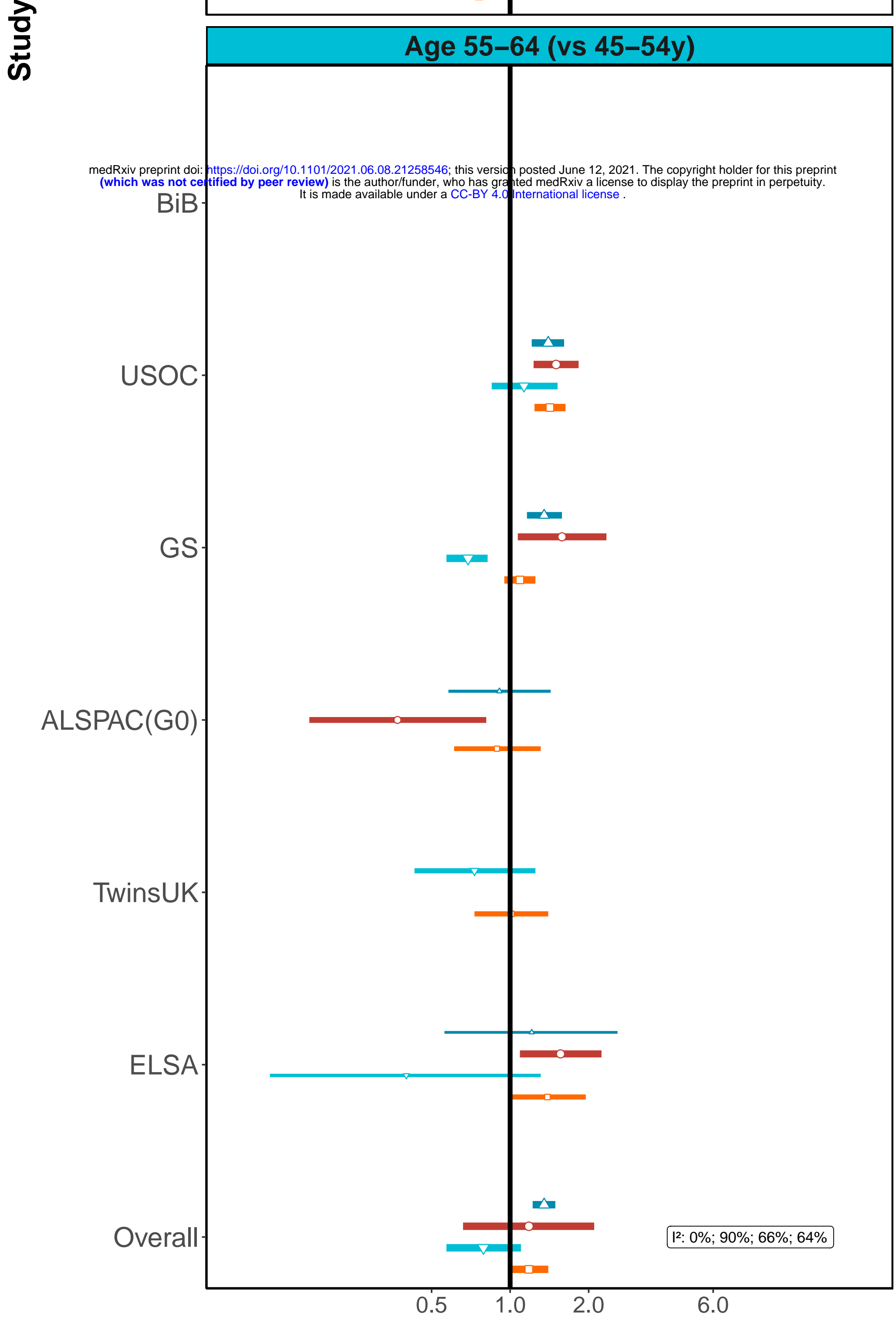

के
के
के

Ae 25-34 (vs 45-54y)

ALSPAC (GO)

ج্े 


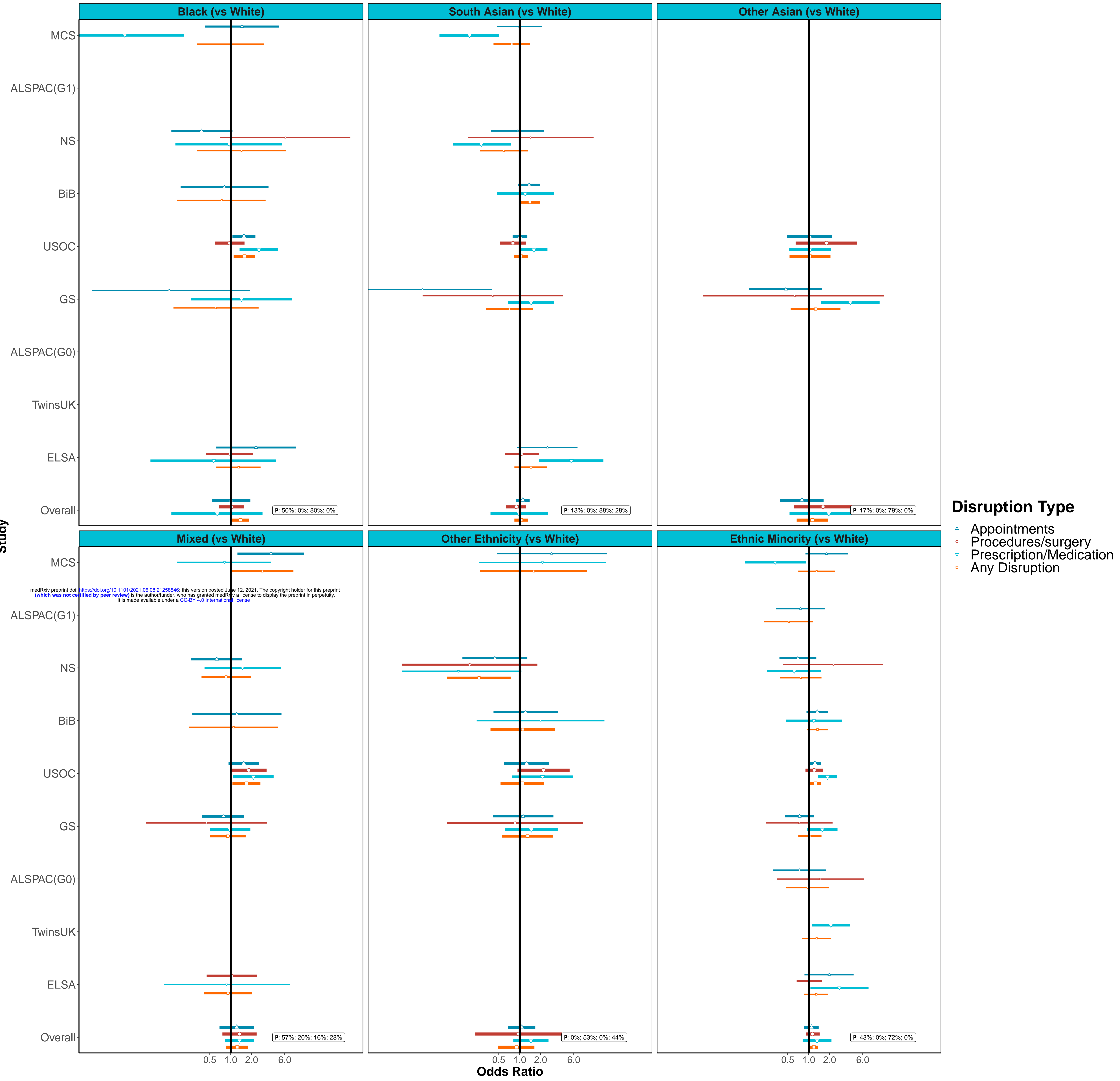




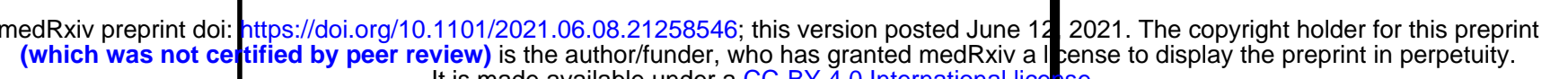
$\operatorname{ALSPAC}(\mathrm{G} 1)$

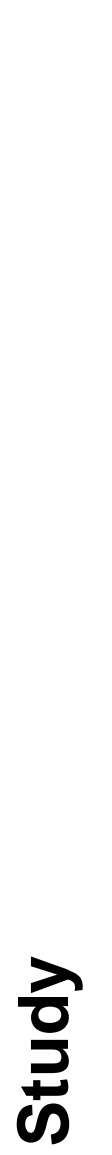

列

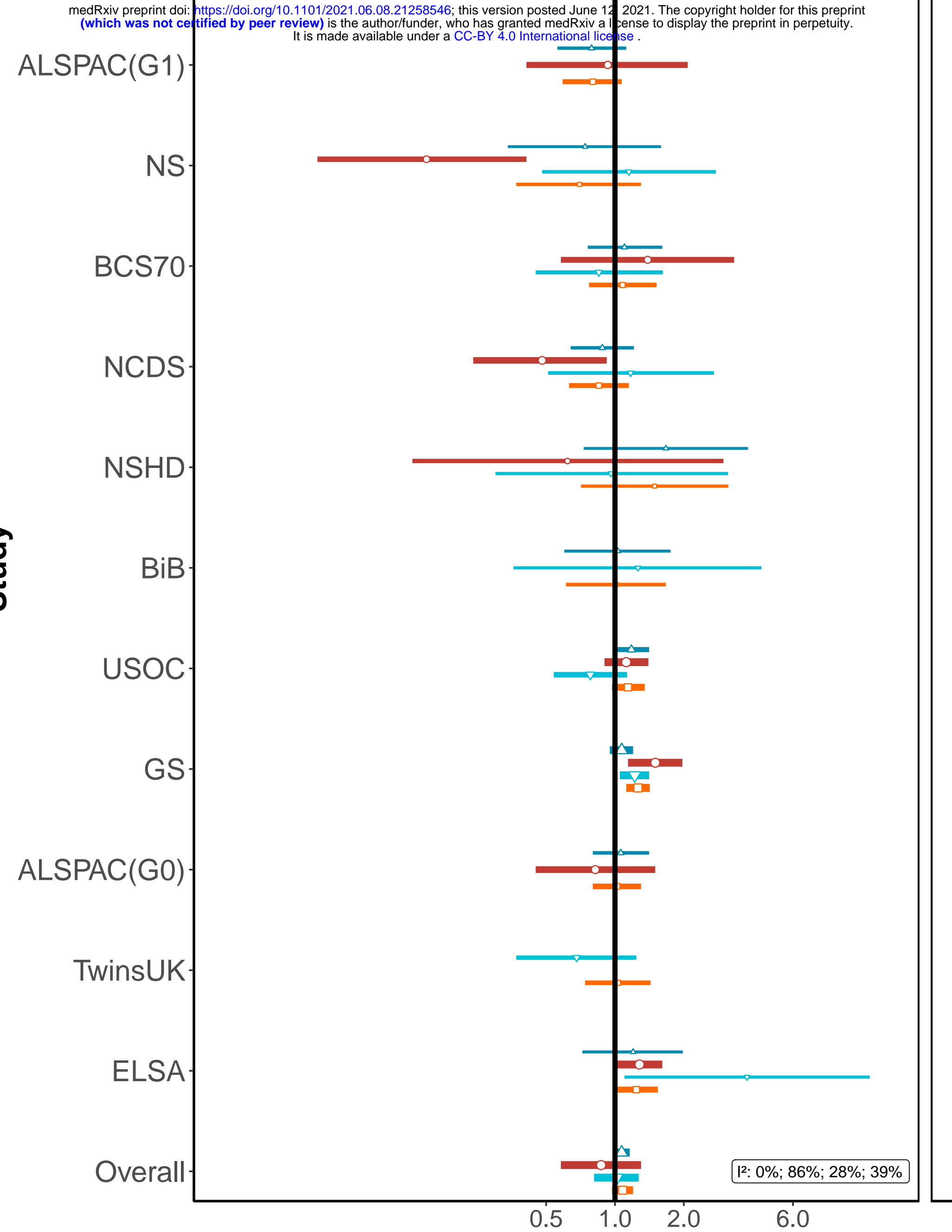

NCDS

NSHD

BiB

USOC

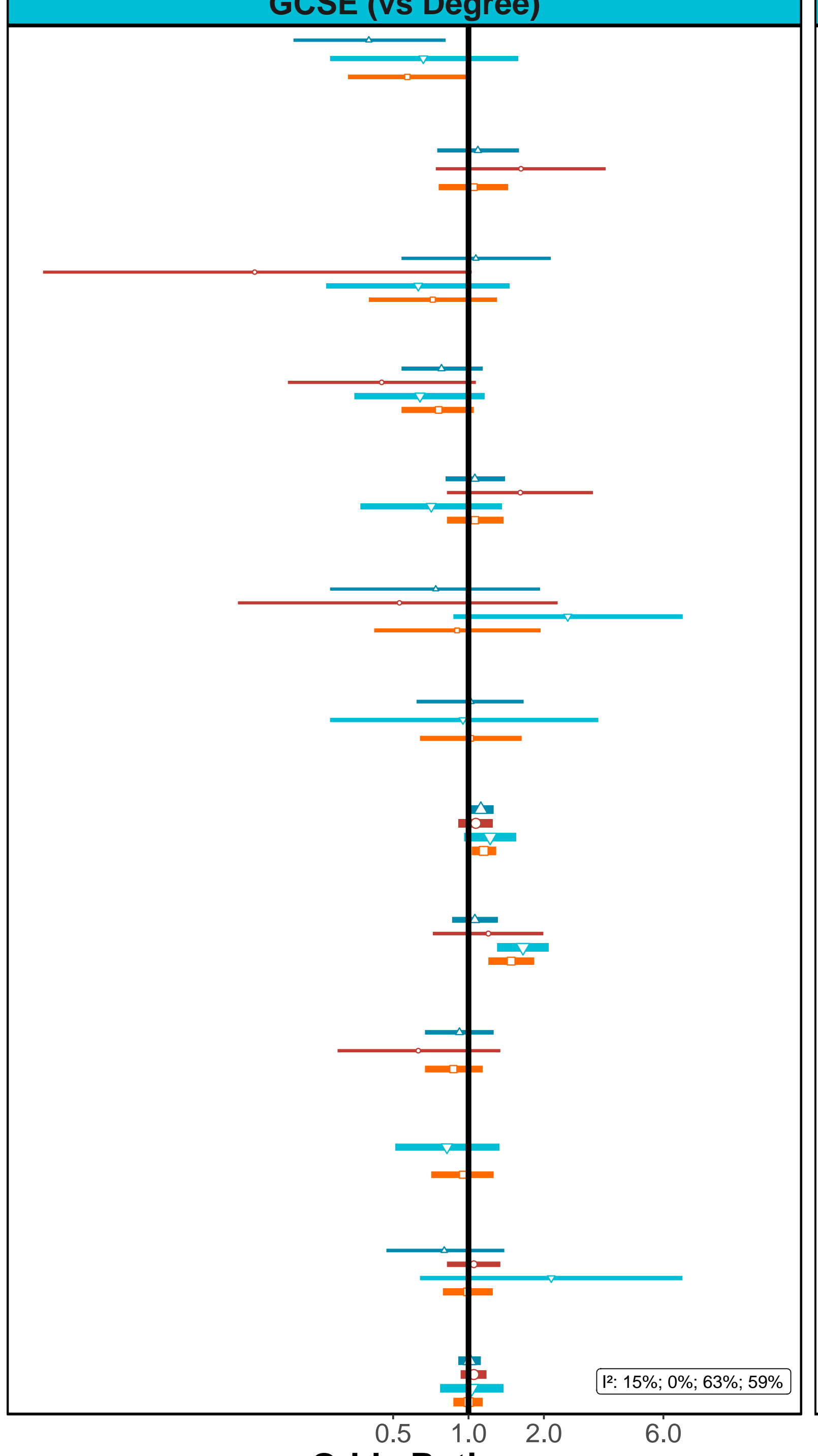

Odds Ratio

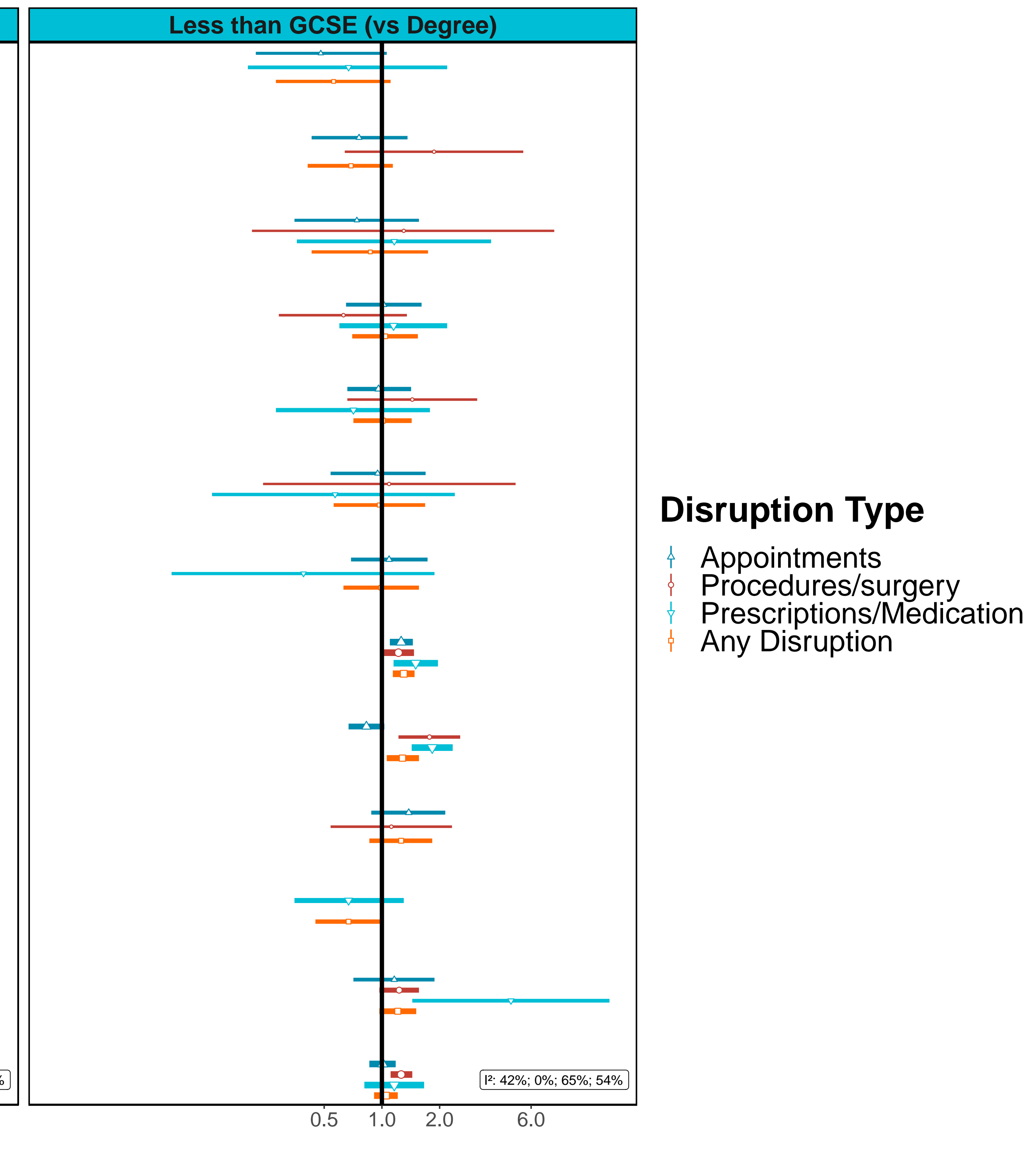



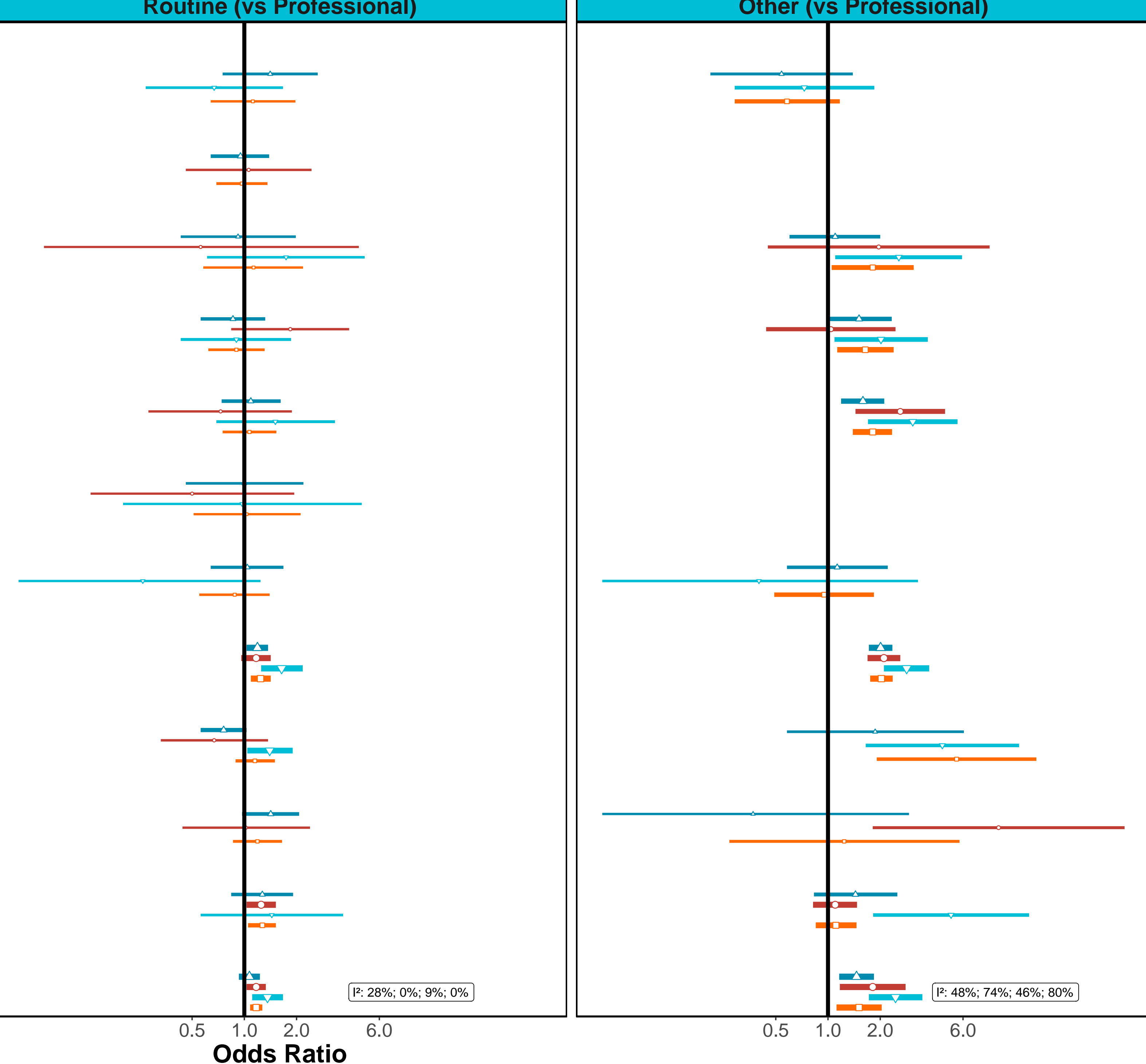

Disruption Type

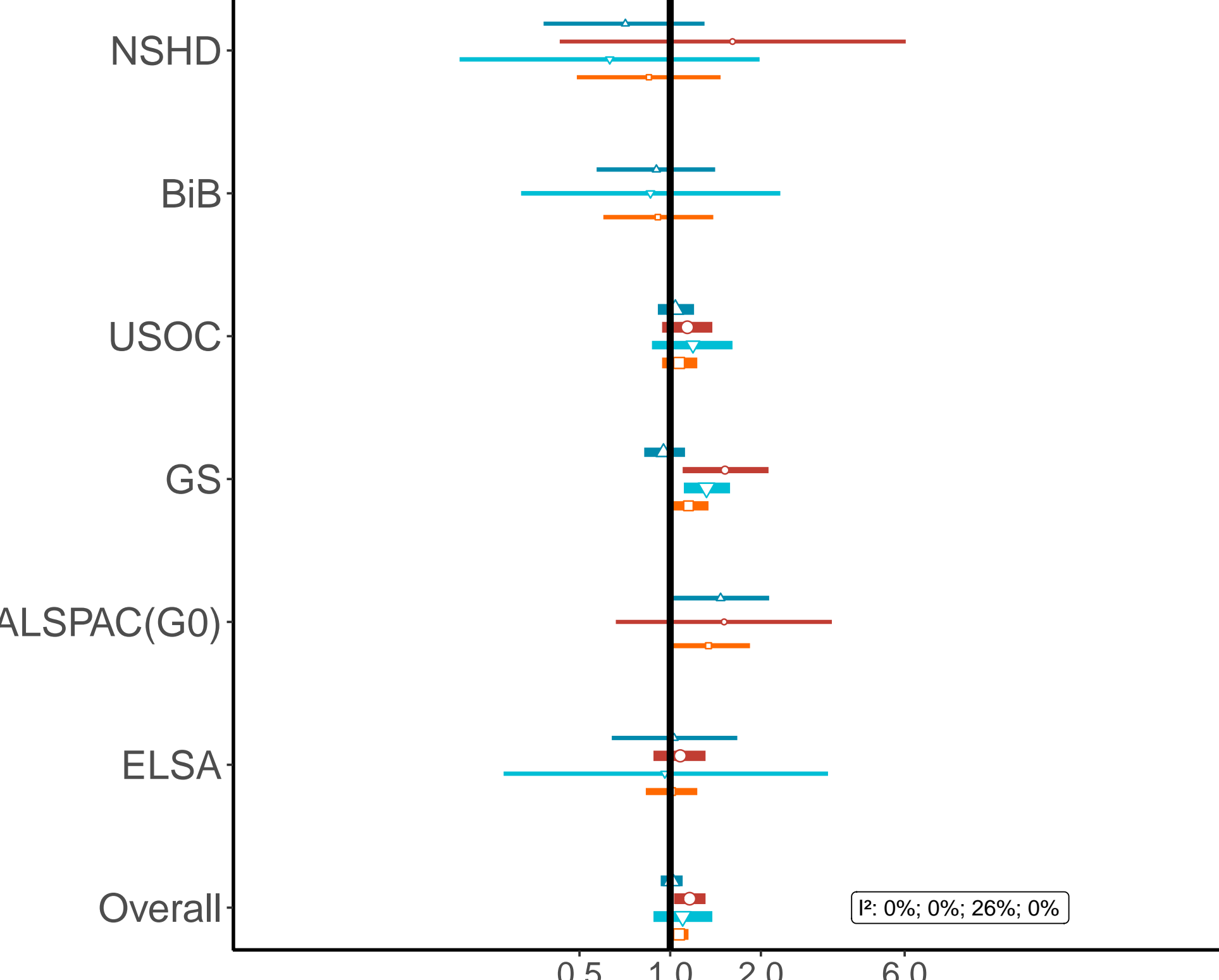

